\title{
Study on Performance of Concrete Made from Sewage Sludge Ceramsite
}

\author{
Junzhe Liu*, Jianbin Chen, Zhimin He, Guoliang Zhang \\ Department of Civil Engineering, Ningbo University, Ningbo 315211, China
}

\begin{abstract}
In this paper, using sewage sludge carried out to manufacture high performance ceramsite. At the same time, the performance of concrete made from sewage sludge ceramsite was analyzed. The results show that the ceramist is mainly composed of cristobalite and mullet, and has dense enamel structure on surface and honeycomb closed fine porous structure in internal. Too large ceramsite size can cause concrete strength decrease, poor stability and workability; mineral admixtures make strength and workability of ceramsite concrete improve, but excessive addition could reduce concrete strength particularly in the early stage, so there is a reasonable dosage; ceramsite concrete strength is increased with the decrease of water-cement ratio, the increase of strength is not obvious when water-cement ratio reduced to a certain extent; increasing sand-ratio can improve concrete strength, but have adverse impact on the workability of fresh concrete.
\end{abstract}

Keywords: Light weight concrete, performance, sewage sludge, ceramsite.

\section{INTRODUCTION}

Over 800 ton sewage sludge is produced in Ningbo every day from sewage treatment plants. The disposal of sewage sludge is mainly "landfill", which exists disadvantages such as large landfill volume, difficult to transport and secondary pollution [1]. Meanwhile, Ningbo is located in China's eastern coast, and has a large number of rivers and lakes. The city produces more than 22 million tons of sludge every year which cannot be disposed. Sewage sludge is composed of rich organic and inorganic components that can be resource utilized [2]. But it is used to aim at the organic composition in utilization, disregarding the inorganic composition. Actually, it is proper and feasible to produce ceramsite by taking advantage of both organic and inorganic components in sewage sludge to replace clay. Therefore, using sewage sludge to produce ceramsite is in line with national industrial policy, and has great development potential and market prospect [3].

\section{RAW MATERIALAND TEST METHODS}

Raw Materials. The sludge was collected from the sewage treatment plant in Ningbo, The silt was collected from the deposition mud in Ningbo Yongiiang, fly ash, got from Ningbo Beilun Power Plant, its chemical composition shown in Table 1. Fig. (1) shows DTA-TG analysis of sludge. Concrete proportion and performance was shown in Table 2. The cement is grade 42.5 ordinary Portland cement, produced by Yadong cement factory in Wuhan, China. The slag is obtained from the wenxi in sanxi province, China. Sea sand fineness-modulus is 2.7 and crushed stone were used.

Experiment Method. The sludge had dried and pulverized, mixed with fly ash evenly in different proportions and add proper water then knead into around $10 \mathrm{~mm}$ diameter geen pellets. The geen pellets were dried for $12 \mathrm{~h}$ at $105^{\circ} \mathrm{C}$ and put into furnace pre-firing for a while,

\footnotetext{
*Address correspondence to this author at the Department of Civil Engineering, Ningbo University, Ningbo, 315211, China; Tel: +86-057487600328; Fax: +86-0574-87600328; E-mail: junzheliu@163.com
}

then, the green pellets will be burned for about $15 \mathrm{~min}$, when the green pellets became to ceramisite and been cooled naturally, the properties and microstructure of the ceramisite will be test.

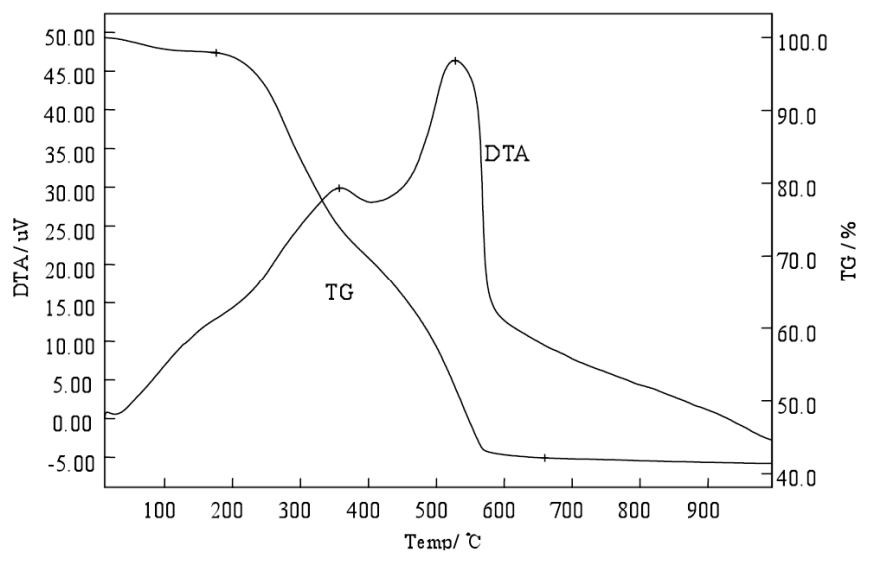

Fig. (1). Thermal analysis of sludge.

Mix Design. In this experiment, we chosed only fly ash as additional material for specimens. The main material was the sludge. From the chemical composition of sludge, if only use sludge fired ceramic, its chemical composition is not satisfied with Reily three phase diagram, which could not have expansion properties for firing ceramsite, according to such reasons, we designed the ingredient plan for the sludge and fly ash [4].

Research has investigated the fine chemical composition of the high-strength ceramisite should be controlled: $\mathrm{W}\left(\mathrm{SiO}_{2}\right)=55 \% \sim 65 \% ; \quad \mathrm{W}\left(\mathrm{Al}_{2} \mathrm{O}_{3}\right)=18 \% \sim 25 \% ; \quad \mathrm{W}\left(\mathrm{Fe}_{2} \mathrm{O}_{3}+\right.$ $\mathrm{FeO})=6 \% \sim 10 \%$; $\mathrm{W}(\mathrm{RO})=4 \% \sim 6 \%$; $\mathrm{W}\left(\mathrm{R}_{2} \mathrm{O}\right)=1.5 \% \sim 4.0 \%$. So we selected the four Ingredients of the program in Table 2 for ceramisite firing.

Pre-firing Parameter Design. The key factor of controlling the pre-firing temperature and the during time of green pellets is the content of free water, bound water and organic matter in green pellets. In this experiment, there is 
Table 1. Chemical Composition of Sludge

\begin{tabular}{|c|c|c|c|c|c|c|c|}
\hline Code & $\mathbf{S i O}_{2} / \%$ & $\mathrm{Al}_{2} \mathbf{O}_{3} / \%$ & $\mathbf{F e}_{2} \mathbf{O}_{3} / \%$ & $\mathbf{M g O} / \%$ & $\mathbf{C a O} / \%$ & $\mathbf{N a}_{2} \mathbf{O} / \%$ & $\mathbf{K}_{2} \mathbf{O} / \%$ \\
\hline \hline Sludge & 56.06 & 9.42 & 12.23 & 4.51 & 6.19 & 7.30 & 4.29 \\
\hline Silt & 65.28 & 12.58 & 7.90 & 2.29 & 5.51 & 2.91 & 3.53 \\
\hline Fly ash & 52.2 & 30.79 & 6.34 & 0.03 & 5.72 & 0.01 & 0.26 \\
\hline
\end{tabular}

Table 2. Concrete Proportion and Performance

\begin{tabular}{|c|c|c|c|c|c|c|c|c|c|}
\hline Code & Cement/kg & Flyash/kg & Slag/kg & Ceramsite/kg & Sand Ratio/\% & $\mathbf{R}_{7} / \mathbf{M P a}$ & $\mathbf{R}_{\mathbf{2 8}} / \mathbf{M P a}$ & Density/(kg/m $\mathbf{3})$ & Slump/cm \\
\hline \hline 1 & 360 & 45 & 45 & 565 & 30 & 34 & 43 & 1767 & 20 \\
\hline 2 & 360 & 45 & 45 & 525 & 35 & 36 & 45 & 1790 & 21 \\
\hline 3 & 424 & 53 & 53 & 565 & 30 & 39 & 51 & 1778 & 23 \\
\hline 4 & 424 & 53 & 53 & 525 & 35 & 42 & 55 & 1810 & 20 \\
\hline
\end{tabular}

few organic content in sludge and fly ash, and we discovered something from the pre-firing:

(1) The green pellet must be completely dried, or else much of the pellets will be found many cracks on the face and more seriously the ball will bursting when put the pellets in furnace. Through analysis, the sludge ratio in the green pellet take a great part, so that the green pellets have features like dense texture, fine pore, high strength and free water is not dried entirely, so when put the pellets in furnace the free water in the green pellets difficult to shed out causing the cracking and bursting, ultimate impacting the ceramic strength.

(2) The higher the firing temperature, the shorter burn out the organic matter in green pellets. Compared to the sludge green pellets, the time of pre-firing for the sludge green pellets in this experiment can be greatly reduced.

According to comparisons, the pre-firing parameter was selected $600^{\circ} \mathrm{C}$ and $20 \mathrm{~min}$ pre-firing time.

Sintering Parameter Design. Sintering is the key process of ceramsite firing. It is put the pre-sintered green pellets into the furnace that is already heated up to the sintering temperature. Measured from the economize on energy point of view, the best sintering ceramsite temperature should not exceed $1200^{\circ} \mathrm{C}$, and consideration from the temperature of making the green pellets expansion, we conducted a test sintering at first, the time is $15 \mathrm{~min}$, the test sintering results showed in Table 3 .

According to results, the designed firing temperature is reasonable, some results can be obtained from the test sintering:

With the increase of sludge ratio in pellets, the expansion temperature is lower. This result help us deal with the sludge, The firing temperature more lower, the less consumption of energy, the higher the sludge composition, the more consumption of river sludge.
(2) The firing temperature range is wide in these formulas for sintering ceramsite. This feature may make the industrialized production of ceramsite easy operable.

(3) The green pellets content $70 \%$ and $60 \%$ sludge were fired melting at $1250^{\circ} \mathrm{C}$. We can find some relationship with the sintering time. The longer the firing time, the larger the pore diameter ceramisite, the density and strength decreased and the water absorption increased significantly.

Table 3. Sintering Results

\begin{tabular}{|c|c|c|c|c|c|}
\hline Proportions & $\mathbf{1 0 5 0}^{\circ} \mathbf{C}$ & $\mathbf{1 1 0 0}^{\circ} \mathbf{C}$ & $\mathbf{1 1 5 0}^{\circ} \mathbf{C}$ & $\mathbf{1 2 0 0}^{\circ} \mathbf{C}$ & $\mathbf{1 2 5 0}^{\circ} \mathbf{C}$ \\
\hline \hline $7: 3: 3$ & $\mathrm{E}$ & $\begin{array}{c}\mathrm{E} \\
\mathrm{En}\end{array}$ & $\begin{array}{c}\mathrm{E} \\
\mathrm{En}\end{array}$ & $\mathrm{SM}$ & $\mathrm{SM}$ \\
\hline $6: 4: 3$ & $\mathrm{NE}$ & $\mathrm{SE}$ & $\mathrm{E}$ & $\mathrm{E}$ & $\mathrm{SM}$ \\
\hline $5: 5: 3$ & $\mathrm{NE}$ & $\mathrm{NE}$ & $\mathrm{NE}$ & $\mathrm{SE}$ & $\mathrm{E}$ \\
\hline $4: 6: 3$ & $\mathrm{NE}$ & $\mathrm{NE}$ & $\mathrm{NE}$ & $\mathrm{NE}$ & $\mathrm{SE}$ \\
\hline
\end{tabular}

Note: Not expansion(NE), Slight expansion(SE), expansion(E), Enameled (En), surface melting(SM).

\section{RESULTS AND DISCUSSION}

Effects of Silt Ratios on Ceramsite Strength. The process of control the temperature of ceramsite get expansion is a key working procedure for high-strength lightweight ceramsite. With the silt ratio increase in pellet, the expansion temperature lower, the various aspects of ceramsite physical properties also change. The variation of crushing strength of ceramsite made from different temperatures and different silt ratios as shown in Fig. (2).

It can be seen from Fig. (2) that the crushing strength is increased with increasing silt ratios at $1050^{\circ} \mathrm{C}, 1100^{\circ} \mathrm{C}$ and $1150^{\circ} \mathrm{C}$. The reason is that there did not form enamel in the pellets with great fly ash ratios at these temperatures, which resulting in the cylinder compressive strength of ceramsite is 
not high. When analyze the chemical composition, we can find the percentage of $\mathrm{Al}_{2} \mathrm{O}_{3}$ increase with the fly ash ratios more, a corresponding increase is the expansion temperature. With the reduction of fly ash, expansion temperature and glazed temperature lower, the cylinder compressive strength also increased [5].

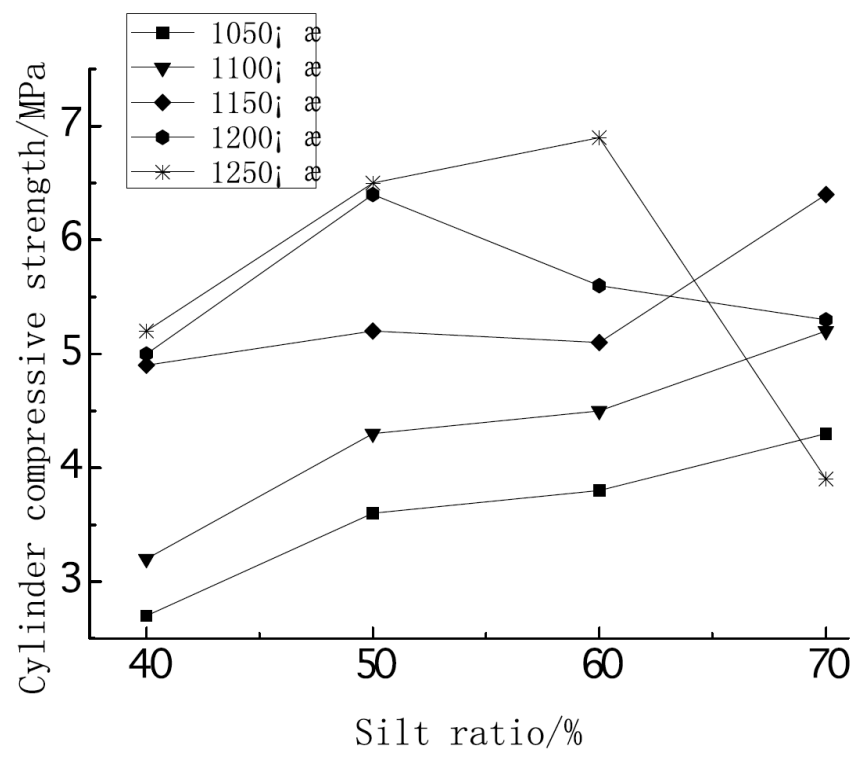

Fig. (2). Effects of sludge ratios on ceramsite strength.

At $1200^{\circ} \mathrm{C}$ temperature, the change range of the cylinder compressive strength is relatively small, the mainly reason is the enamel layer which formed in all kinds of pellets at this temperature. The $70 \%$ silt ratio ceramsite have big holes inside, enamel of cell wall, connected holes. In the firing process the near pellets were melting together, which affect the strength of the ceramsite, the cylinder compressive strength decrease.

The $1250^{\circ} \mathrm{C}$ intensity curve can be seen the first three intensity is increased with silt content, $70 \%$ silt content of the ceramic strength decreases rapidly, because at this temperature, the ceramsite had burned.

Effects of Silt Ratios on the Density and Water Absorption. The density of ceramsite is closely related to the ceramsite expansion or not, the degree of the ceramsite glaze effects the water absorption, firing expansion and degree of glazing were influenced by the chemical composition, firing temperature and length of the sintering time. We set the sintering time is $15 \mathrm{~min}$, the variation is shown in Figs. $(\mathbf{3}, \mathbf{4})$.

In Fig. (4), at the temperature of $1250^{\circ} \mathrm{C}$ the water absorption rapidly increase because with the silt content increased, the hole wall enameled and the connective pore in ceramsite increased, water absorption increased as well.

Effects of Sintering Temperature and Time on the Performance. We are aware of the sintering temperature and time have a larger influence on the ceramsite properties. The ceramsite made in factory need to have a wide effective expansion temperature range and appropriate sintering time. Through comprehensive compare the properties of ceramistes which made from different sludge ratios and several sintering temperature, we select $70 \%$ sludge ratio of green pellets sintering at diverse temperature and diverse time. The results of different sintering time are shown in Table 4, the sintering temperature is $1150^{\circ} \mathrm{C}$.

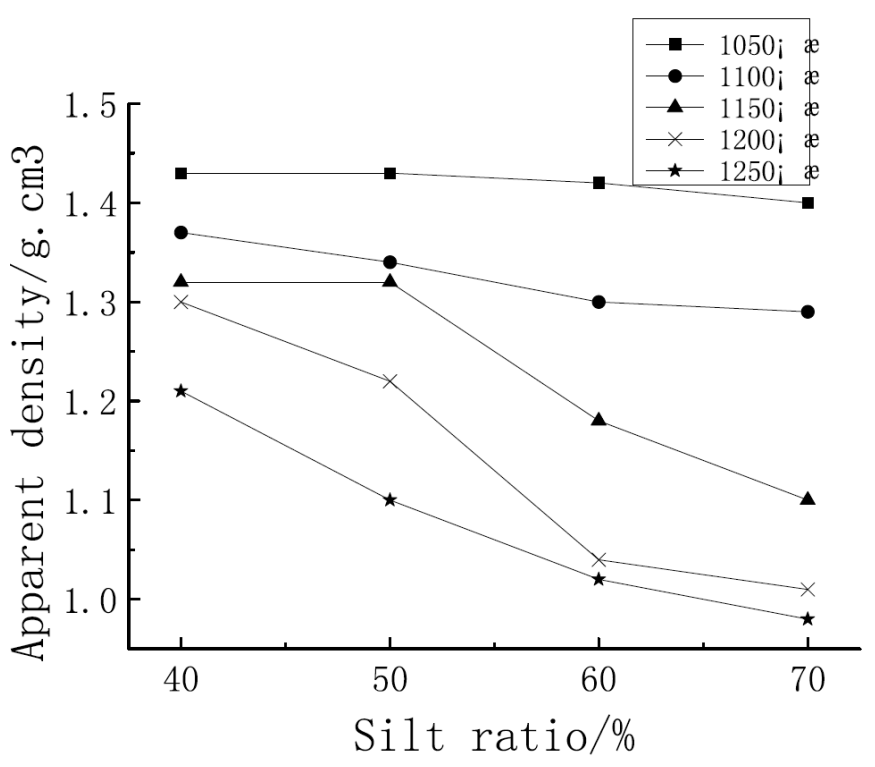

Fig. (3). Effects of silt ratios on the density.

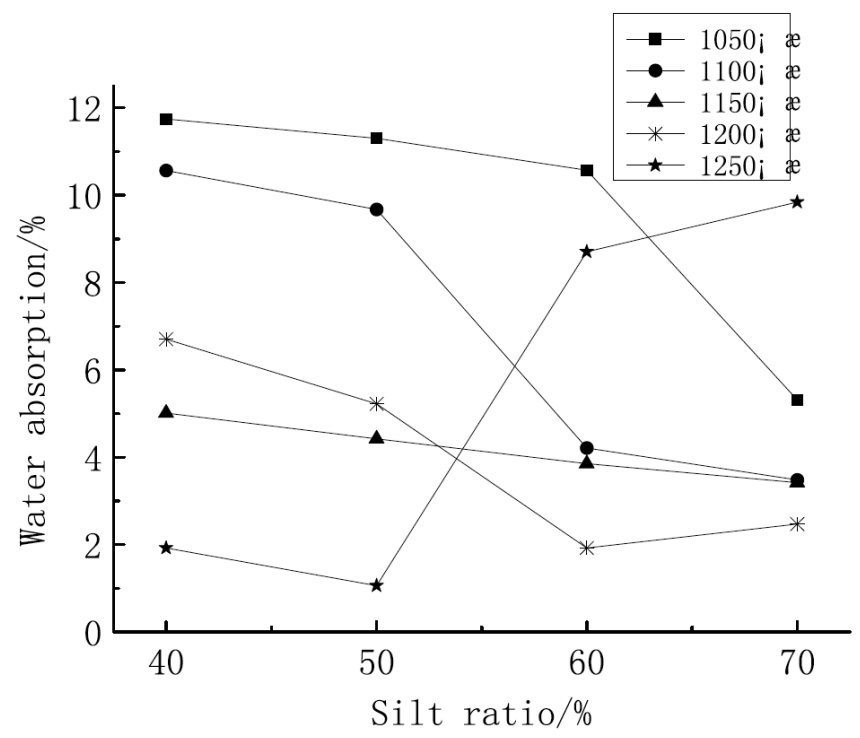

Fig. (4). Effects of silt ratios on the water absorption.

Table 4. Effects of Sintering Time on the Performance

\begin{tabular}{|c|c|c|c|}
\hline $\begin{array}{c}\text { Performance } \\
\text { Sintering } \\
\text { Time }\end{array}$ & $\begin{array}{c}\text { Cylinder } \\
\text { Compressive } \\
\text { Strength [MPa] }\end{array}$ & $\begin{array}{c}\text { Bulk } \\
\text { Density } \\
{\left[\mathbf{K g} / \mathbf{m}^{\mathbf{3}}\right]}\end{array}$ & $\begin{array}{c}\text { Water } \\
\text { Absorption [\%] }\end{array}$ \\
\hline \hline $10 \mathrm{~min}$ & 5.3 & 845 & 6.55 \\
\hline $15 \mathrm{~min}$ & 6.4 & 783 & 3.44 \\
\hline $20 \mathrm{~min}$ & 6.8 & 759 & 2.82 \\
\hline $25 \mathrm{~min}$ & 4.7 & 710 & 10.96 \\
\hline
\end{tabular}

Referring to Figs. (2-4), we find that the ceramsite strength increase with the sintering temperature rise, the apparent density decrease and the water absorption reduce. When the temperature is above $1250^{\circ} \mathrm{C}$, the ceramsite properties have a sudden change, which include the cylinder 
compressive strength and the apparent density significantly reduced, but the water absorption increased sharply. All these indicating that the liquid phase of the sludge ceramsite had a great developed at $1250^{\circ} \mathrm{C}$, the gas making the ceramsite expansion rapidly overflow, so greatly increased the internal rate of ceramsite pores, pore size increases, thereby reducing its physical properties. Gotta look at those sludge ratios in the $1100^{\circ} \mathrm{C} \sim 1200^{\circ} \mathrm{C}$ all got fine physical properties.

As can be seen from Table 4, the best sintering time for performance are $15 \mathrm{~min} \sim 20 \mathrm{~min}$. During this time, you can sintering out the packing density is 700 grade ceramsite, water absorption is low and the cylinder compressive strength has reached a good level, as shown in Fig. (5). Table 5 was Entrust detecting results.

\section{Table 5. Sludge Ceramsite Performance}

\begin{tabular}{|c|c|c|c|c|c|c|}
\hline Code & \multicolumn{5}{|c|}{ Test Type } & Results \\
\hline \multirow{3}{*}{1} & \multirow{3}{*}{ Grade } & \multirow{3}{*}{\multicolumn{3}{|c|}{ Accumulate residue on sieve (\%) }} & $16.0 \mathrm{~mm}$ & 11 \\
\hline & & & & & $10.0 \mathrm{~mm}$ & 93 \\
\hline & & & & & $5.0 \mathrm{~mm}$ & 100 \\
\hline 2 & \multicolumn{5}{|c|}{ Bulk density $\left(\mathrm{kg} / \mathrm{m}^{3}\right)$} & 687 \\
\hline \multirow{2}{*}{3} & \multirow{2}{*}{\multicolumn{2}{|c|}{ Strength (MPa) }} & \multicolumn{3}{|c|}{ Tube strength } & 6.6 \\
\hline & & & \multicolumn{3}{|c|}{ Cylinder compressive strength } & 40 \\
\hline 4 & \multicolumn{5}{|c|}{ Water absorption (\%) } & 0.6 \\
\hline 5 & \multicolumn{5}{|c|}{ softening coefficient } & 0.96 \\
\hline 6 & \multicolumn{5}{|c|}{ grain-type coefficient } & 1.1 \\
\hline \multirow{7}{*}{7} & \multirow{7}{*}{ 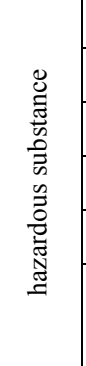 } & \multicolumn{4}{|c|}{ Mass loss in boiled water (\%) } & 0.6 \\
\hline & & \multicolumn{4}{|c|}{ LOI (\%) } & 0.4 \\
\hline & & \multicolumn{4}{|c|}{ sulfide and sulfate (\%) } & 0.1 \\
\hline & & \multicolumn{4}{|c|}{ clay content $(\%)$} & 0 \\
\hline & & \multicolumn{4}{|c|}{ Organic conctents } & qualifiedd \\
\hline & & \multirow{2}{*}{\multicolumn{2}{|c|}{ active nucleus }} & \multicolumn{2}{|c|}{$\mathrm{I}_{\mathrm{Ra}}$} & 0.38 \\
\hline & & & & \multicolumn{2}{|c|}{$\mathrm{I}_{\gamma}$} & 0.64 \\
\hline
\end{tabular}

Performance of ceramsite concrete. Figs. (6-8) shows too large ceramsite size can cause concrete strength decrease, poor stability and workability; supplementary cementations materials make strength and workability of ceramsite concrete improve, but excessive addition could reduce concrete strength particularly in the early stage, so there is a reasonable dosage; ceramsite concrete strength is increased with the decrease of water-cement ratio, the increase of strength is not obvious when water-cement ratio reduced to a certain extent; increasing sand-ratio can improve concrete strength, but have adverse impact on the workability of fresh concrete.

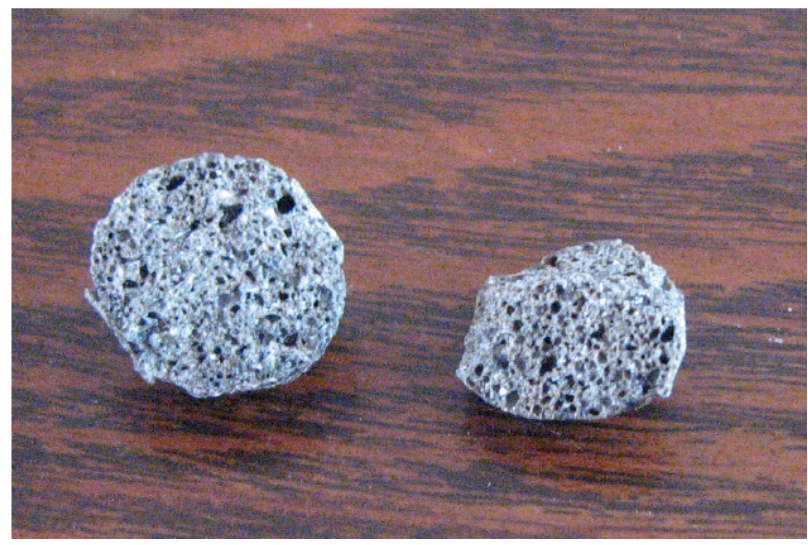

Fig. (5). Internal porous structure of ceramsite.

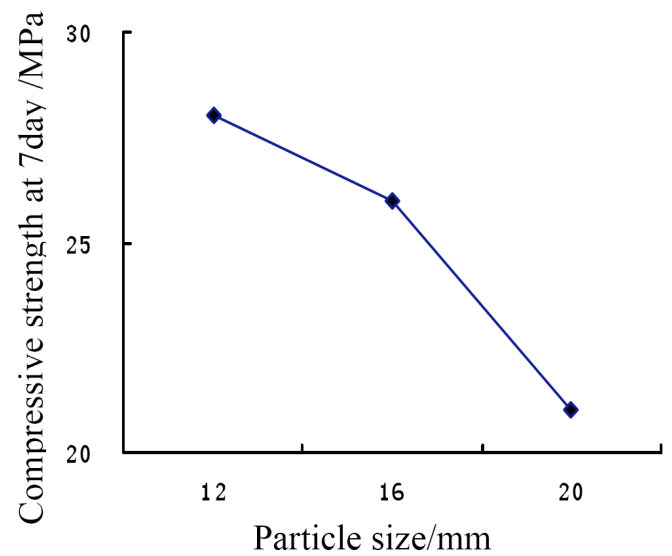

Fig. (6). Effect of ceramsite size on concrete strength.
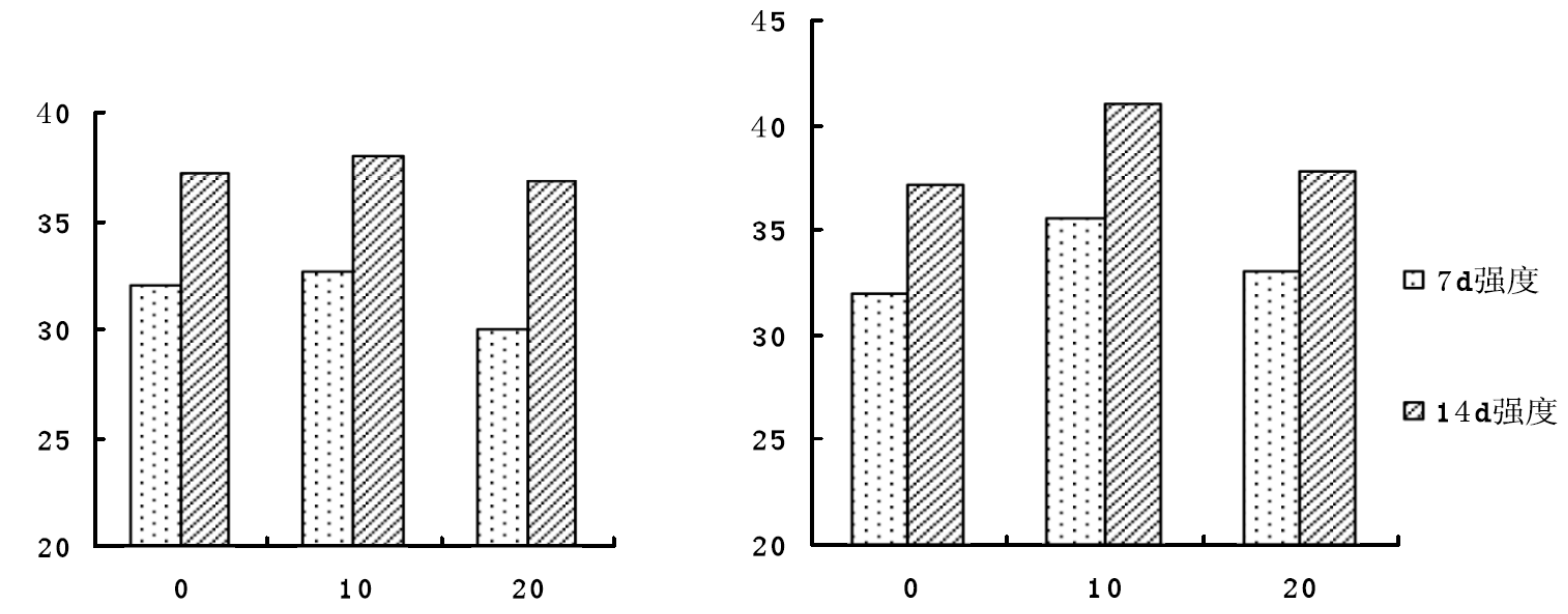

Fig. (7). Effect of mineral admixtures on concrete compressive strength. 

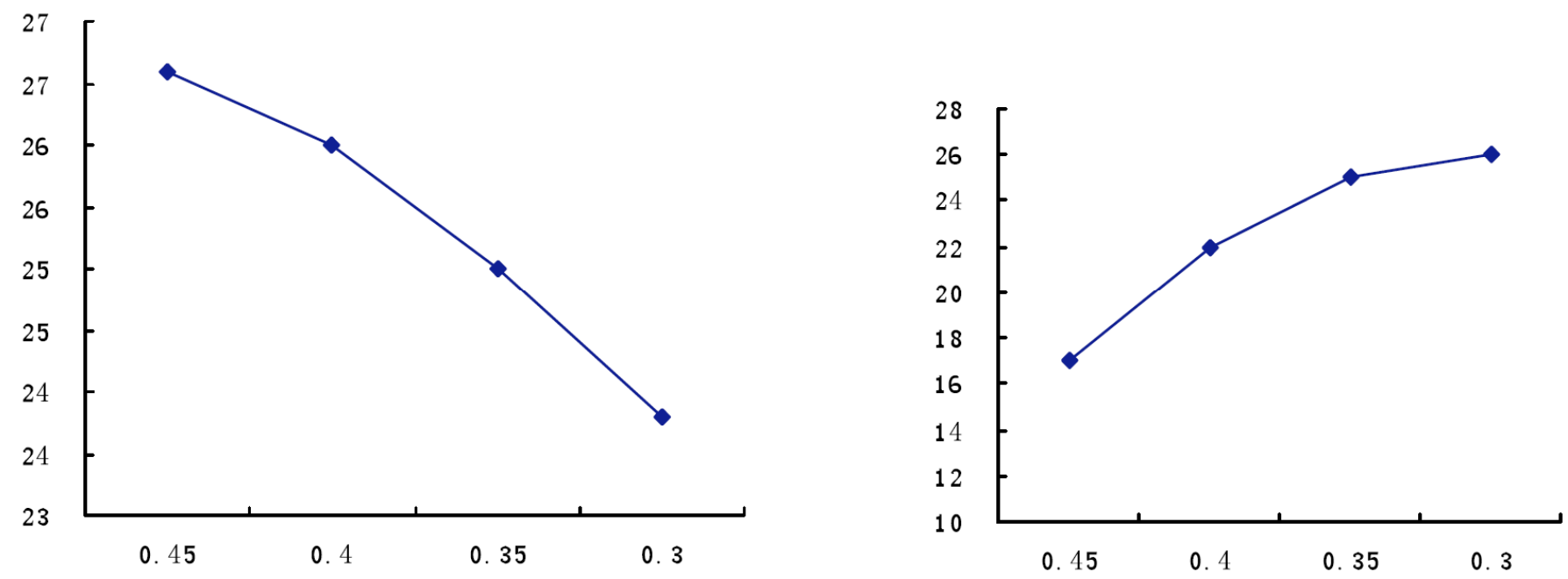

Fig. (8). Effect of water cement ratio and sand ratio on concrete compressive strength.

Microstructures of Sludge Ceramsite. After SEM analysis of sludge ceramsite, it can be observed from Fig. (9), the surface of the sludge ceramsite has dense enamel layer, from the SEM picture, the surface is almost not observed the existence of tiny openings hole. This surface characteristic determined the low water absorption of the self-made ceramsite. In Fig. (10), through the internal pore structure of sludge ceramsite we can see the self-made ceramsite has honeycomb structure inside. The honeycomb pore structure wide spread in ceramsite which determined high strength and light performance characteristics. Sludge ceramsite X-ray diffraction analysis shown in Figs. $(\mathbf{1 1}, \mathbf{1 2})$. From the enamel layer of sludge ceramsite we can found in XRD pattern the main crystalline phases of the surface on self-made ceramsite is mullite. Mullite is a very important product for sintering ceramsite, it is a skeleton for ceramsite as well as formed high strength ceramsite. Mullite is a very important factor to the high strength microstructure formation. Cristobalite and mullite make the ceramsite have high strength and low water absorption $[6,7]$.

Ceramsite concrete performance. Using sewage sludge ceramsite can produce green high performance concrete.

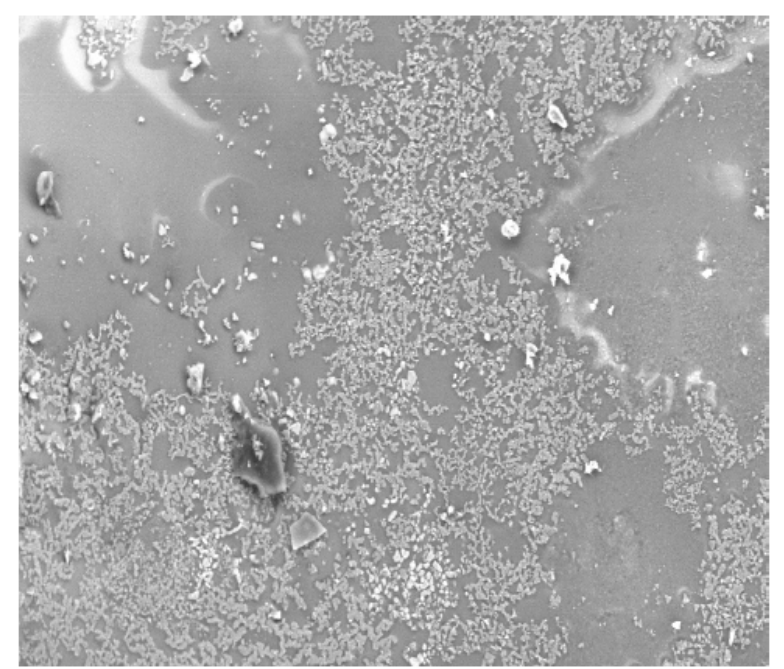

Fig. (9). Surface crystal structure sludge ceramsite.

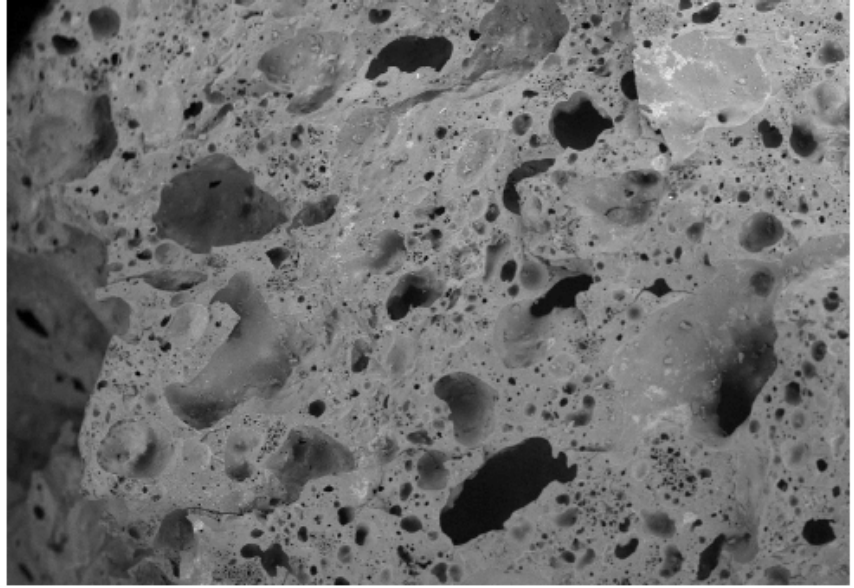

Fig. (10). Internal pore structure of sludge ceramsite.

when size of ceramsite too large can cause strength decrease, poor stability and workability; mineral admixtures make strength and workability of light weight aggregate concrete improve, but excessive addition could reduce concrete strength particularly in the early stage, so there is a

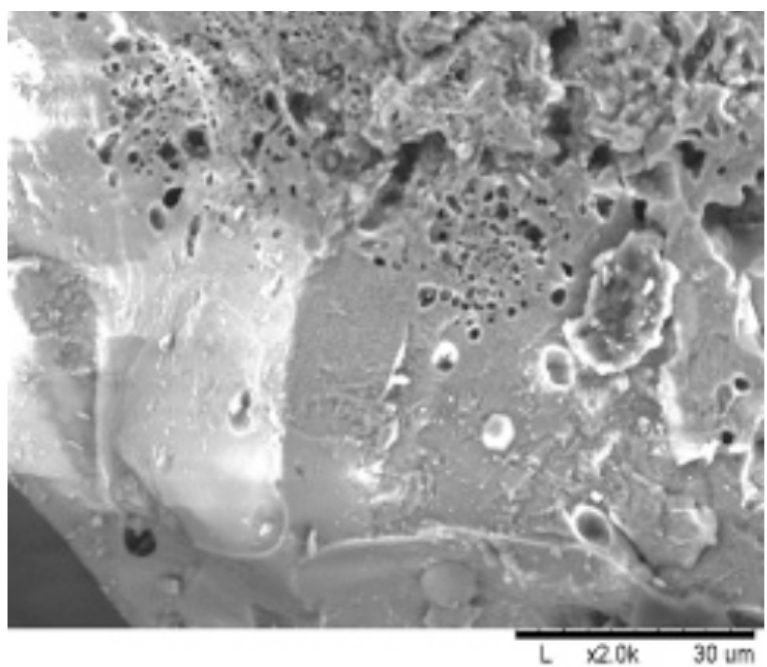




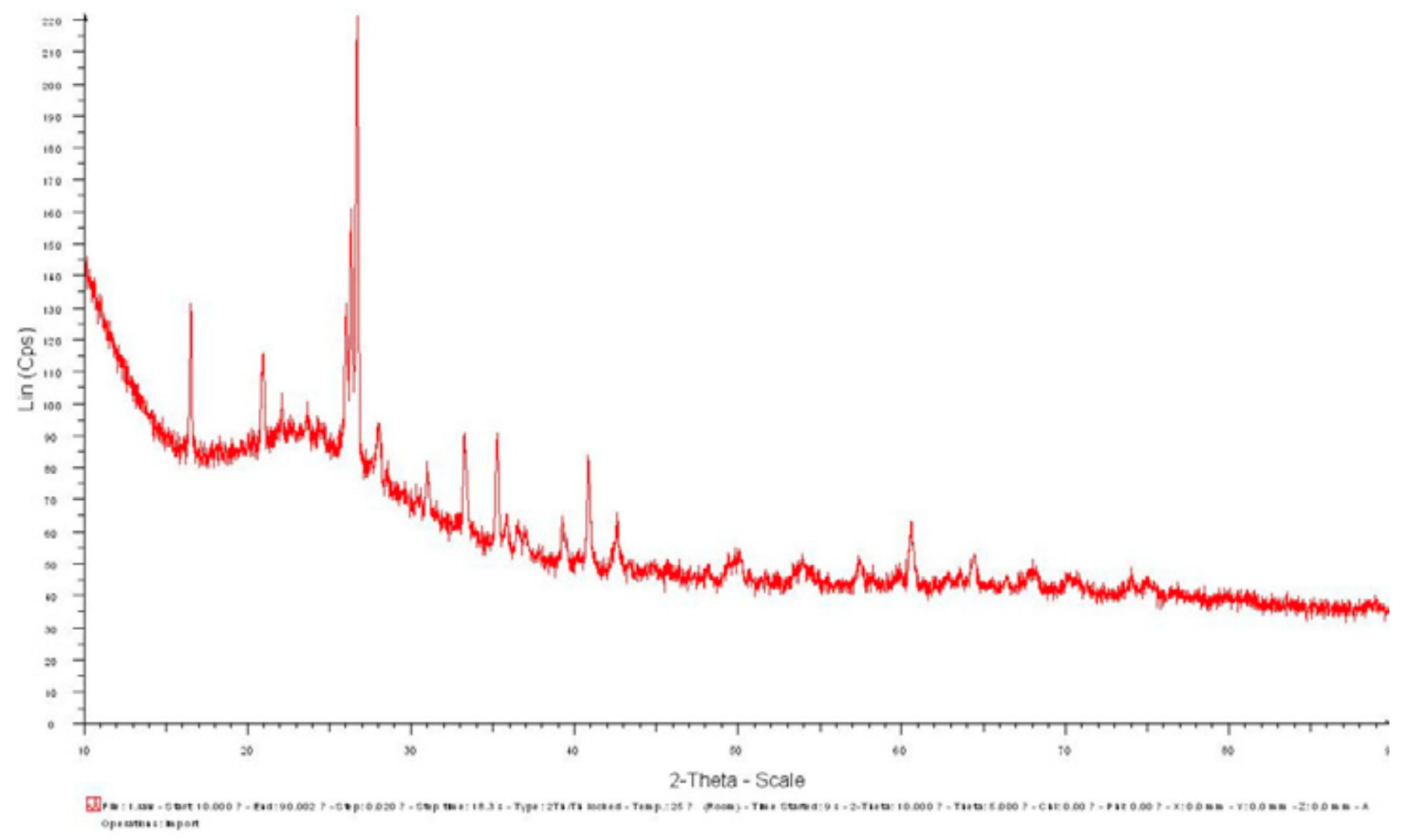

Fig. (11). Surface crystal structure silt ceramsite.

reasonable dosage; light weight aggregate concrete strength is increased with the decrease of water-cement ratio, but for the limit of strength of light weight aggregate, the increase of strength is not obvious when water-cement ratio reduced to a certain extent; increasing sand-ratio can improve concrete strength, but have adverse impact on the workability of fresh concrete. Using the study results, optimized the concrete mix proportion and prepared grade 40 light weight aggregate concrete with density level $1700 \mathrm{~kg} / \mathrm{m}^{3}$, slump degree over $18 \mathrm{~cm}$, extended degree over $50 \mathrm{~cm}$.

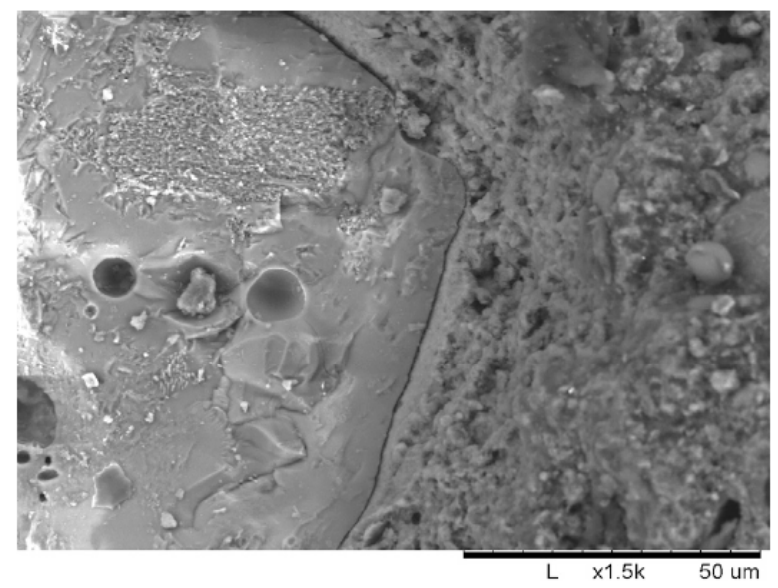

\section{CONCLUSIONS}

1. In a different amount of sludge ratio after different sintering temperature, through contrasted the various physical properties of the different kinds of ceramsite, we finally found an ideal formula and firing mechanism of the sludge ceramsite and got a highperformance ceramsite that density level is 800 grade, water absorption is $2.82 \%$, cylinder compressive strength is $6.8 \mathrm{MPa}$. The reasonable ceramsite mixing sludge is $60 \%$ to $70 \%$, if the sludge ratio is lower,

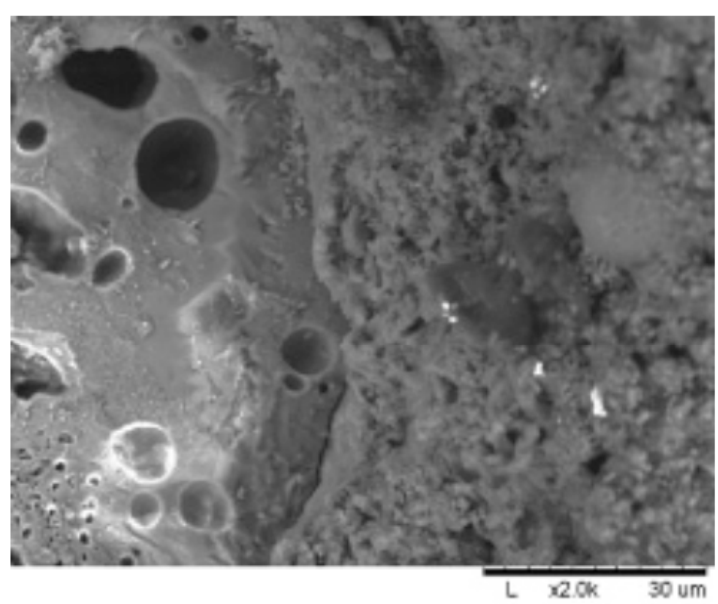

(a)

(b)

Fig. (12). SEM of ceramsite concrete interface. 
will increase the sintering temperature, if the sludge ratio is higher than this range, the chemical composition will not reach the requirements of expansion of sludge ceramsite; more reasonable sintering temperature range is $1100^{\circ} \mathrm{C} \sim 1200^{\circ} \mathrm{C}$ sintering time is $15 \mathrm{~min} \sim 20 \mathrm{~min}$.

2. Using sewage sludge ceramsite can produce green high performance concrete, when size of ceramsite too large can cause strength decrease, poor stability and workability; supplementary cementations materials make strength and workability of LWAC improve, but excessive addition could reduce concrete strength particularly in the early stage, so there is a reasonable dosage; LWAC strength is increased with the decrease of water-cement ratio, but for the limit of strength of LWA, the increase of strength is not obvious when water-cement ratio reduced to a certain extent; increasing sand-ratio can improve concrete strength, but have adverse impact on the workability of fresh concrete.

\section{ACKNOWLEDGEMENTS}

This work has been supported by Zhejiang province energy conservation innovative team project in building (2009R50022) and the Ningbo subject project (SZX11062).

\section{REFERENCES}

[1] Gong L. Development of light weight aggregate bridge engineering. Construct Technol 2003; 9: 1-3.

[2] Gong Luoshu. The development and view of light-weight aggregate concrete technique. Concrete 2002; 2: 13-15.

[3] Jiantong D, Yushun G, Kimura K. State of the application of structural lightweight aggregate concrete in foreign countries. Concrete 2000; 9: 23-26.

[4] Liu X. Strength and strength grades of LWAS. Housing Mate Appl 1999; 1: 6-11.

[5] Du X. Research on technology and batch formula of sintering municipal sewage sludge for manufacturing haydite. Sichuan Building Mater 2009; 4: 61-63.

[6] Tay J H, Show K Y, Hong S Y. Concrete aggregates made from sludge-marine clay mixes. J Mater Civil Eng 2002; 11: 392-398.

[7] Nakouzi S, Mielewski D, Ball J C, et al. Novel approach to paint sludge recycling. J Mater Res 1998; 1: 53-60. 